\title{
WOMEN IN THE MULTIPLE FIELD OF TENSION: EVERYDAY WARTIME LIFE IN EAST PRUSSIA
}

\author{
Ruth Leiserowitz (iD
}

\begin{abstract}
The article analyses the everyday life of civilians in East Prussia during the Second World War, with a special focus on the Klaipeda (Memel) region, a former territory of Lithuania, which was annexed by the German Reich in March 1939. Since the Wehrmacht recruited a large number of men in 1941 in the former Memel region, a great shortage of labour also arose in this northern part of East Prussia. At the same time, numerous labour camps were set up in the region, for both foreign and forced labourers, and prisoners of war. Foreign workers were employed in most agricultural enterprises, which were run by women, thus creating many sources of tension. The women were dependent on close cooperation with the workers, but had to keep a safe distance and report to the Nazi authorities, as well as to their men who were on the front line. The paper focuses on the situation of women who lived and worked in familiar surroundings during the war, but whose lives were nevertheless greatly influenced by the war. KEYWORDS: Second World War; East Prussia; Memel/Klaipeda region; the history of everyday life; forced labour; women in Nazi Germany; women in the Second World War.
\end{abstract}

\section{ANOTACIJA}

Straipsnyje analizuojama civilių gyventojų kasdienybė Rytų Prūsijoje Antrojo pasaulinio karo metais, ypatingą dèmesi kreipiant i Klaipédos kraštą, buvusią Lietuvos teritoriją, kuri 1939 m. kovą buvo vèl prijungta prie Vokietijos Reicho. Kadangi 1941 m. daug vyru buvusiame Klaipédos regione užverbavo Vermachtas, šioje šiaurinejje Rytų Prūsijos dalyje taip pat atsirado didelis darbo jejgos trūkumas. Tuo pat metu šiame regione buvo isteigta daugybè darbo stovyklų, skirtų tiek užsieniečiams ir priverstiniams darbininkams, tiek karo belaisviams. Užsienio darbininkai buvo įdarbinti daugiausia žemès ūkio įmonèse, kurioms dabar vadovavo moterys, tuo užprogramuojant daugybę pačių ivairiausių ịtampų. Moterys buvo priklausomos nuo glaudaus bendradarbiavimo su darbininkais, tačiau turejjo laikytis aiškios distancijos ir atsiskaityti nacių valdžiai, taip pat savo vyrams, kurie buvo fronto linijose. Straipsnyje daugiausia dèmesio skiriama moterų, kurios karo metu gyveno ir dirbo joms gerai pažįstamoje aplinkoje, bet kurių gyvenimo situaciją vis dèlto masiškai paveikè karas, padéčiai aptarti.

PAGRINDINIAI ŽODŽIAI: Antrasis pasaulinis karas; Rytų Prūsija; Klaipėdos kraštas; kasdienybės istorija; priverstinis darbas; moterys nacių Vokietijoje; moterys Antrajame pasauliniame kare.

Ruth Leiserowitz, Prof. Dr., deputy director, German Historical Institute Warsaw, al. Ujazdowskie 39, PL-00540 Warszawa, Poland. E-mail: leiserowitz@dhi.waw.pl. 


\section{Introduction}

It is not unusual for new perspectives and aspects to emerge when a topic is examined more closely. This has also been the case here while reading and researching. For this reason, the article has been given a different heading to what was announced in the programme. The following starting points were important for my considerations. On one hand, I wanted to shed a light on the situation of women who lived and worked in familiar surroundings during the war, but whose life situation was nevertheless massively influenced by the war. On the other hand, I wanted to make a contribution to the time of the Second World War in East Prussia, because everyday wartime life still plays no role in East Prussian memories today. It is generally assumed that the easternmost province of the German Reich was not affected by the war for a long time. I am also interested in how everyday life in the countryside changed during the war. I am particularly interested in peasant women, who ran farms and farmed during the war. It is time to ask how women coped with everyday life in East Prussia during the Second World War, and what additional tasks they faced in order to mark this period, biographically and historically. My thesis is that there were extreme challenges during the war, especially for women in the countryside, because the exceptional 'war' situation had a strong influence on the range of actions of women. This consideration is quite contrary to the common claim that 'East Prussia was an island of the blessed' in the horror of the Second World War. ${ }^{1}$ However, these factors have never been specifically highlighted and addressed, as they were completely overshadowed by the challenges posed by flight and the end of the war. Therefore, actual everyday life during the war, with all its facets and difficulties, has been completely pushed into the background.

\section{Women on the home front}

Methodologically, this article ties in with reflections from my former publication with Maren Röger 'Women and Men at War', ${ }^{2}$ even though it deals with what happened in the home country during the war. I have in mind especially peasant women, women who ran farms and farmed during the war. With a few exceptions, the sources are taken from published literature. ${ }^{3}$ In this context, I would like to refer in particular to

KOSSERT, Andreas. Damals in Ostpreußen. Der Untergang einer deutschen Provinz. München, 2008, S. 7.

2 RÖGER, Maren; LEISEROWITZ, Ruth. Introduction: Gender and World War II in Central and Eastern Europe. In Women and Men at War. A Gender Perspective on World War II and its Aftermath in Central and Eastern Europe. Ed. by Maren RÖGER; Ruth LEISEROWITZ. Osnabrück, 2012, pp. 9-32.

3 TILITZKI, Christian. Alltag in Ostpreußen 1940-1945. Die geheimen Lageberichte der Königsberger Justiz, 19401945. Leer, 1991; ARBUŠAUSKAITĖ, Arūnè Liucija; BUBNYS, Arūnas. Nazi Germany-Controlled POW Camps in the Environs of Šilute 1939-1944. In Macikai House of Death: The WWII prisoner of war and Gulag camps 19391955 in the environs of Šilute. Ed. by Edita JANKAUSKIENĖ. Vilnius, 2020, pp. 19-59; DORN, Ursula; JÄNICKE, Gisbert. Ich war ein Wolfskind aus Königsberg. Biographischer Roman. Salzburg, 2011, S. 16; LACHAUER, Ulla. 
the new monograph by Raffael Scheck, who has carried out extensive research on love relationships between West European prisoners of war and German women during the Second World War. ${ }^{4}$ Although the East Prussian region plays only a minor role in his study, he can refer to an excellent contemporary witness in this context.

Everyday wartime life lay primarily on the shoulders of women. Even before the war broke out, rationing and the introduction of food stamps had been planned. This was done by the 'Decree for the Provisional Securing of the Vital Needs of the German People of 27 August 1939'. ${ }^{5}$ Especially for the inhabitants of the Memel district, who had celebrated their annexation by the German Reich with great euphoria, this new restriction dampened the mood. There were different consequences for the city and the countryside in the next period, which will only be briefly outlined here, insofar as they had an influence on the everyday life of women and families. These included the coal shortage in the cold winter of 1940, when 75,000 families in Königsberg alone could not be supplied with fuel in one day. ${ }^{6}$ It was even reported that 'Due to the completely insufficient coal supply, children's hands froze in their beds. ${ }^{7}$ It was also reported that there was a 'sudden rise in food prices'. ${ }^{8}$ Although Memelland was again part of the German Reich from the spring of 1939, local conditions were not equal in many respects. There were differences to the so-called Altreich (the 'Old Empire' was the name for the territory of the German Empire within the borders of 1937) in various areas. For example, the retail trade in Memel had problems obtaining goods from the Old Empire. ${ }^{9}$ Kurt Friedrici, from the district of Heydekrug, remembers that food rationing cards were obligatory during the war. There was an obligation to pay a levy on milk, and a permit had to be obtained for the sale and slaughter of pigs. ${ }^{10}$

\section{Memories of the First World War in East Prussia}

It is an old law that in the face of the outbreak of war, memories of events of the last war become louder. ${ }^{11}$ During the First World War, a good 25 years earlier, East Prus-

Paradiesstraße. Lebenserinnerungen der ostpreußischen Bäuerin Lena Grigoleit. Reinbek bei Hamburg, 1997; MORGENSTERN, Erika. Überleben war schwerer als Sterben/Ostpreußen 1944-1948. Kiel, 1999.

4 SCHECK, Raffael. Love between Enemies. Western Prisoners of War and German Women in World War II. Cambridge, 2021.

5 Verordnung über die Wirtschaftsverwaltung, 27.8.1939. Reichsgesetzblatt, 27.8.1939, Nr. 149, S. 14951498; Verordnung über die öffentliche Bewirtschaftung von landwirtschaftlichen Erzeugnissen, 27.8.1939. Reichsgesetzblatt, 28.8.1939, Nr. 150, S. 1521-1526.

6 TILITZKI, C. Op. cit., S. 105.

7 Ibid., S. 106-109, here S. 108.

8 Ibid., S. 106-109, here S. 107.

9 Bericht des Generalstaatsanwalts (i.V.: OStA Capeller) vom 14. April 1940. In TILITZKI, C. Op. cit., S. 106110, here S. 110.

10 Script: V. Simanauskas interviews Kurt Friederici (born 1932) in Kintai in May 1999.

11 During our project 'Nations, Borders, Identities: The Revolutionary and Napoleonic Wars in European Memories (1815-1945)' we have repeatedly been confronted with the fact that at the beginning of a war, 
sia, as a region bordering the Russian Empire, was the only area of the German Empire directly affected by acts of war. In August 1914 and March 1915, two different waves of forced migration occurred in opposite directions. On one hand, the populations of various towns and villages fled the Russian army in a westward direction. The second wave affected German civilians who remained in the region. They were arrested by the Russian occupying forces and taken to the interior of Russia. Most refugees who had taken refuge in the west had returned by 1916. Civilian deportees who were in Russia did not return until 1919, as their repatriation was delayed by the turmoil of the revolution and the ensuing civil war. Consequently, stories of flight were the main element in the narratives of memory. Foreign prisoners of war and forced labourers, who were an everyday phenomenon in East Prussia during the Second World War, also existed during the First World War. But at that time, they were used mainly in groups for work. Overall, there was very little individual contact with prisoners of war. In the social order still existing at the time, it would have been unthinkable for a woman to work alone with a foreign prisoner of war. This was to change dramatically during the Second World War, especially in rural areas.

\section{The Second World War in East Prussia}

Everyday life during the Second World War plays a barely perceptible role in East Prussian memories, for it is precisely in the area north of the Memel that the story of the return of the Memel district in the spring of 1939 towers over it. On the other hand, the extensive memories of the epochal events of the flight still overshadow the events of the preceding years. ${ }^{12}$ This phenomenon runs through all social classes. Even in contemporary records and the memoirs of Marion Gräfin Dönhoff, one of the most prominent East Prussian women of the time, there is hardly any place for everyday wartime life. Here, stories about organising the political resistance, the failure of the 20 July assassination attempt, and even most recently the escape narrative, dominate. ${ }^{13}$

In the early summer of 1941, the province became a deployment area for the imminent invasion of the USSR. For the first time, the civilian population felt that things were getting serious. Kurt Friederici, whose parents, according to his statement,

memories from the last war dominated more and more, and literature about the last war was read. A paradigm for this is the reading of Tolstoy's War and Peace during the Leningrad blockade. (For more about the project: https://nbi.sites.oasis.unc.edu/).

12 Interviews conducted by my students at the then Centre for West Lithuanian and Prussian History at Klaipeda University in the spring of 1999 show that for the years 1939 and 1944 very colourful memories were present among the respondents, and could be told very vividly. For the years 1940-1943, however, hardly any events could be recalled.

13 DÖNHOFF, Marion. Ritt durch Masuren. Aufgeschrieben 1941 für meinen Bruder Dietrich. Leer, 1992; SCHWARZER, Alice. Marion Dönhoff. Ein widerständiges Leben. Köln, 2002. 
owned a farm of 50 hectares in Barzduhnen (Heydekrug district), recalls that in the early summer of 1941, about 60 German soldiers were stationed there. ${ }^{14}$ Lena Grigoleit from Bittehnen later said: 'At Midsummer in 1941, the war came to us. I still remember exactly how it broke out. In the evening, the soldiers lay outside the window, ready to jump. They wore camouflage dress and warned me to look out for the children in the next few days: "Watch out, we're leaving at three o'clock tonight." It was already light when the shooting started. In the evening, wounded soldiers were already coming back. Afterwards, the front always went forward, always ahead, and we stayed behind and kept on working. ${ }^{15}$

For four years, the front was far away from East Prussia, and reports about it existed only in letters from the soldiers and the narrations of those on leave from the front.

The changed everyday life in the country

Various factors caused significant changes in villages of the East Prussian region. One of them was the impact of the bombing of cities inside the Reich. Schoolchildren were sent to faraway East Prussia with the Kinderlandverschickung (the evacuation of children in Germany during the Second World War). ${ }^{16}$ The population of the city was also advised to go to regions that were not within the radar of the British bombers. Thus, women with small children were also sent to the countryside. ${ }^{17}$ To the general situation, it should be added that soldiers' wives whose husbands had been drafted received family support through the Wehrmacht Welfare and Supply Office. ${ }^{18}$ This financial support was graded according to rank, and often enabled women not to work. Especially in the countryside, this led to misunderstandings and conflicts. The rural population had plenty of work to do, and could not understand why the guests did not want to cooperate. ${ }^{19}$

Even before the war, the volume of work in agriculture had been shouldered only with the help of seasonal workers. In 1941, the Wehrmacht recruited a large number of men in the former Memel district, resulting in a particularly severe labour shortage. Thus, the attorney general in East Prussia, Szelinski, the president of the Oberstes Landesgericht (Supreme Regional Court), noted in his report of 29 May 1943: 'In East Prussia, which is known in the Empire as a soldier's land, the popula-

14 Script: V. Simanauskas interviews Kurt Friederici (born 1932) in Kintai in May 1999.

15 LACHAUER, U. Op. cit., S. 44.

16 USCHTRIN, Günter. Wo liegt Coadjuthen? Die Geschichte eines ostpreußischen Kirchspiels im ehemaligen Memelland. Berlin, 2011, S. 288-290.

17 KOSSERT, A. Op. cit., S. 7.

18 KRETSCHMAR, Hans. Zum gegenwärtigen Stand der kriegsfinanzpolitischen Frage. Zeitschrift für die gesamte Staatswissenschaft, 1942, Bd. 102, Hf. 4, S. 654-701, here S. 661.

19 TILITZKI, C. Op. cit., S. 257. 
tion's regrouping has become increasingly noticeable over the course of the war. Men of military age have seldom returned home $[. . .]^{\prime 20}$ At the same time, East Prussia became a very large territory for labour camps for foreign and forced labourers, as well as prisoners of war. Nazi institutions made a strict distinction between prison camps for Soviet prisoners of war and those for French, Belgian and Anglo-American prisoners of war. South of the Memel was Stalag IA Stablack, where in 1940 and 1941, 23,000 Belgian and 37,500 French prisoners of war were imprisoned, and who were taken from there to various work assignments in East Prussia. North of the Memel were Oflag 53 (first in Heydekrug, then in Pogegen), Oflag 63 in Prökuls, and Stalag IC (331C) in Heydekrug (which was later renamed Stalag ID), Stalag ID/Z in Pogegen, Stalag IF/Z in Prökuls, and Stalag Luft 6 in Heydekrug. ${ }^{21}$ One has to imagine how the Nazi regime, through its warfare, tore the majority of men at their most productive age out of the work process and life context in order to wage war with them, and in return transplanted cohorts of men of the same age and physical condition into another context under humiliating circumstances. This sounds schizophrenic in the face of the ideology of the Nazi state, which dreamed of a purebred national body. It was obvious that this situation put everyone involved under additional stress.

The prisoners of war were mostly used individually on farms. It had to be ensured that they were housed separately from the residential building. This meant that they slept in the stable, behind the feed chamber, or the laundry room. ${ }^{22}$ In the evenings, it had to be checked whether the prisoner was there. Overnight, he had to be locked up. ${ }^{23}$ At irregular intervals, a guard made the rounds of the yards to check their presence. ${ }^{24}$ These guards were mainly older men who were no longer deployed at the front. To that extent, these workers were under constant surveillance. Obviously, positions of racial ideology had to be softened in the face of economic requirements. ${ }^{25}$

During the war, the East Prussian province was under the jurisdiction of a single Gau labour office, with its headquarters in Königsberg. If, in the following, more examples are given for northern East Prussia and Memelland than for Masuria, this selection in no way detracts from the general statements. Masuria, i.e., southern East Prussia, differed with regard to the general situation of the province only insofar as Hermann Göring had already prohibited the deployment of Poles in March 1940 in areas where it was feared that this might cause a particular danger to the national population. ${ }^{26}$ Masuria was one of these territories.

20 Ibid., S. 237-254, here S. 243.

21 LIETZ, Zygmunt. Obozy jenieckie w Prusach Wschodnich, 1939-1945. Warszawa, 1982.

22 SCHULZ, Erhard. Kindheit in Ostpreußen und Flucht 1944/45. Erinnerungen. Norderstedt, 2019, S. 77.

23 Ibid., S. 101.

24 Ibid., S. 94.

25 HERBERT, Ulrich. Fremdarbeiter. Politik und Praxis des "Ausländereinsatzes" in der Kriegswirtschaft des Dritten Reiches. Berlin, 1999, S. 13.

26 VERGIN, Ute. Die nationalsozialistische Arbeitseinsatzverwaltung und ihre Funktionen beim Fremdarbeiter(innen) einsatz während des Zweiten Weltkriegs. Dissertation zur Erlangung des Doktorgrades. Osnabrück, 2008, S. 268. 


\section{Fields of tension}

In those days, peasant women had an excess of work and obligations. Family and farm needed to be provided for, and the children also lacked a father. In addition, they were concerned about the welfare of their husbands, who were on the front line, and from whom they usually received hardly any news, because correspondence was usually sparse. Non-verbal areas of tension unfolded, because many men also worried that their wives would be unfaithful during their long absence. However, the agricultural business had to be run, and foreign workers were employed for this purpose, which also programmed further different tensions.

It was perceived very clearly in the village community which assigned workers brought benefits to the farms. Envy was also inevitable. Anna Ginsel, a farmer's wife from Wabbeln (Heydekrug district), reported after the war that she, her husband who was disabled in the war, and their son, managed a farm of 85 hectares. ${ }^{27}$ When the son was drafted in 1941, they received a French POW as a labourer, who proved to be very capable. Later, the husband died, and a farmer from Uszlöknen, who was a member of the NSDAP, requisitioned the Frenchman for his farm. The farmer's wife Ginsel was left without help, and had to use all possible means to get the labourer back, which finally succeeded, although none of the requested authorities wanted to mess with a party comrade. But it turned out that this farmer was not formally entitled to the assistance of a prisoner of war at all.

The women were dependent on close cooperation with the workers, but had to keep a clear distance, and were often in dual control situations. Additional pressure weighed on the peasant women, for they were observed suspiciously in the village community, as to whether they separated themselves correctly from the forced labourers in the Nazi sense, and whether they were fulfilling the obligations that the national community expected of them. In a decree of 7 May 1940, Himmler, as head of the German police, ordered that women who dealt with prisoners of war in a manner that grossly violated the 'healthy national sentiment' were to be taken into protective custody. ${ }^{28}$ This expression left many possibilities for interpretation. Again and again, the judicial authorities also pointed out that women in particular did not understand 'how to treat their workers fairly but with the necessary distance'. ${ }^{29}$

Erika Morgenstern gives a snapshot of this complicated communication in her memoirs: 'One day my two-year-old sister got diarrhoea. There was no doctor far and wide. Nothing was more obvious than to ask Johann [the French foreign worker] what we

27 Memelländer besuchen ihre Gefangenen. Frau Ginsel hat „ihren“ Franzosen eingeladen - Er brachte die Kinder nach Westen. Memeler Dampfboot, 1963, Jhg. 114, Nr. 4, S. 44-45.

28 Bericht des OLG Präsident vom 4. Januar 1941. In TILITZKI, C. Op. cit., S. 131-132.

29 TILITZKI, C. Op. cit., S. 267-274, here S. 272. 
should do. But my mother was not allowed to go to the stable and ask him as easily as I could. ${ }^{30}$ The historians Arūnè Arbušauskaitė and Arūnas Bubnys quote in their essay a case in which a farmer's wife, Anna Maria Waitschies from Wirkieten, was punished with four months in prison because she had treated the French prisoner of war Morris Defer, who worked for her, too kindly, and he was allowed to eat with her at their table. However, the accused managed to have the sentence overturned in a higher court. ${ }^{31}$

These burdens on peasant women were much higher than on women living in cities. Admittedly, they also had to take on a high level of work and obligations. However, when they had contact with foreign workers it was mostly limited to purely working hours, and contact hardly ever took place in isolated situations.

However, women also reported that losses of family members at the front offered them a certain amount of protection, as the authorities usually showed some consideration. Lena Grigoleit, for example, who was married to a Lithuanian and was closely watched by the Gestapo in 1939, recounts that this surveillance lessened during the war: 'My brother Arthur was killed near Moscow, my foster brother Walter at the Battle of Stalingrad. Arthur's and Walter's deaths saved my life. I believe that, even if it is perhaps a sin. In all situations where someone suspected me, I could always say: "Our family has given two men for the fatherland." That sentence was like a protective shield. ${ }^{32}$

\section{Sexuality and war}

My contribution aims to show that women were also challenged in their domestic environment during the war in an extreme way by the circumstances. We are used to seeing female soldiers, partisans and other heroines, or numerous victims, for example of sexual violence, under the heading 'Women in War'. However, if we look closely, we see that there could have been extreme challenges at home as well, and that questions of sexuality in war do not necessarily have to be related to soldiers in the foreground.

The attorney general (Chief Public Prosecutor Capeller) reported as early as 14 April 1940 about Memel: 'An increase in commercial abortions of Lithuanian women workers. Interventions are being carried out in Lithuanian border towns, hence no possibility of taking criminal action against women workers from Memel. ${ }^{133}$ This statement must be seen against the background of the fact that abortion was prohibited in Nazi Germany. However, relatively little is known about the context. Were

30 MORGENSTERN, E. Op. cit., S. 43.

31 ARBUŠAUSKAITE், A.; BUBNYS, A. Op. cit., pp. 33-34.

32 LACHAUER, U. Op. cit., S. 47-48.

33 Bericht des Generalstaatsanwalts (i.V.: OStA Capeller) vom 14. April 1940. In TILITZKI, C. Op. cit., S. 106110, here S. 110 . 
Lithuanian women and girls forced or coerced into sexual relations? Probably such incidents cannot be reconstructed after such a long time. As the war progressed, an East Prussian chief public prosecutor even took the view that many women no longer considered intimate relationships with foreign workers 'particularly despicable, but [...] even as a kind of "female peccadillo"'. ${ }^{34}$

In 1943, in his report of 29 May, the attorney general complained about the declining moral standards of many women. He also justified this with a 'certain sexual distress' that caused women to 'enter into love relationships in disregard of their honour as wives and mothers'. In this connection, he quoted the chief public prosecutor in the town of Insterburg, who had stated: 'The numerous foreign workers not only represent a great danger to security, especially in the flat country [...] they gradually endanger the people by blood.'35

Arūnè Arbušauskaitè and Arūnas Bubnys documented some cases in the Heydekrug district. ${ }^{36}$ For example, a Polish officer prisoner of war is said to have had sexual contact with an agricultural worker in the village of Žemaitkiemis. There was also a court case because the farmer's wife Meta Herzam from Skirwieth became pregnant by Robert Seine, a Belgian prisoner of war working for her. Seine was transferred to another farmer, and Seine and Herzam both denied before the district court having had intimate relations. Nevertheless, Herzam was fined. ${ }^{37}$

The farmer's wife Josepha Pusbatzkies from Leitgirren was found in a clear situation with a Belgian prisoner of war. (Her husband was at the front, and fell in Russia in 1943.) The woman was first beaten, and then handed over to the Gestapo. Nothing is known about her further fate. ${ }^{38}$ This is only a small selection of the cases mentioned by Arbušauskaitè and Bubnys.

The different types of penalties seem confusing. ${ }^{39}$ Some kind of explanation for this can be found in the report of the attorney general of 26 January 1944, where he explained: 'The courts, but above all the special court in Königsberg, have tried to fight the epidemic spread of this crime [an increase in traffic with prisoners of war and foreign workers] by means of harsh prison sentences. Through the practice of clemency of the Reich minister of justice, the effects of these sentences have been

34 Bericht des Generalstaatsanwalts (OLG-Präsident Szelinski) vom 26. Januar 1944. In TILITZKI, C. Op. cit., S. 267-274, here S. 270.

35 Bericht des Generalstaatsanwalts (OLG-Präsident Szelinski) vom 29. Mai 1943. In TILITZKI, C. Op. cit., S. 237-254, here S. 244.

36 ARBUŠAUSKAITĖ, A.; BUBNYS, A. Op. cit., pp. 29-30.

37 Ibid., p. 31.

38 Ibid., p. 55.

39 In this work, too, the inconsistency of jurisprudence is pointed out, but also the manifold defence strategies of women. SCHWARZE, Gisela. Es war wie Hexenjagd. Die vergessene Verfolgung ganz normaler Frauen im Zweiten Weltkrieg. Münster, 2010. 
impaired, if not completely, then at least to a great extent. Since the courts have of course not remained unaware of this practice of clemency, they now tend to issue milder punishments. This is now resulting in an inconsistent jurisprudence. ${ }^{\prime 40}$

So much for voices from the legal authorities. The historian Raffael Scheck was able to identify in his research the records of Georges Smets, who acted as a confidant of the more than 23,000 Belgian POWs of Stalag IA in the Forties. ${ }^{41}$ In this regard, it is worth mentioning that POWs of states that had signed the Geneva Convention received legal assistance in court proceedings. (Soviet and Polish POWs were not granted this right by the German Reich. The USSR was not a signatory to the Geneva Convention, and with regard to the Poles, the German authorities argued that the Polish state had perished, and therefore Polish soldiers were no longer a subject of international law. ${ }^{42}$ )

Scheck describes the following: 'Georges Smets attended many court martials in Königsberg, and left a lively description of the procedures. He and the German attorney met approximately one hour before the start of the hearings in a small restaurant near the court building to discuss the last details of the defence with the accused prisoners, who arrived in the company of their guards. Often, the women with whom the prisoners had been involved also gathered in this restaurant, because they were called as witnesses.' And he continues: 'These young ladies were not guarded, and did not hide their affection for their sweethearts. Touching scenes occurred, despite the intervention of the furious guards. The women often brought goodies to the site. Pieces of bread and sausage discreetly slipped into the vast pockets of the prisoners. ${ }^{\prime 43}$

It is also mentioned that 'Some witnesses, such as the Belgian man of confidence Georges Smets, accused these judges and prosecutors of voyeurism.' ${ }^{\prime 4}$ It must have been very unpleasant for the accused women when they had to explain in detail how the forbidden approach (especially the physical one) had taken place. At that time, it was not at all common to talk about sexual matters in public.

\section{True love}

The spectrum of contact was very broad. There was everything, from a fleeting flirtation to a love adventure, to the development of a deep relationship. Future marriag-

40 Bericht des Generalstaatsanwalts (OLG-Präsident Szelinski) vom 26. Januar 1944. In TILITZKI, C. Op. cit., S. 267-274, here S. 270.

41 SCHECK, R. Op. cit., p. 21.

42 FORWICK, Helmuth. Zur Behandlung alliierter Kriegsgefangener im Zweiten Weltkrieg. Anweisung des Oberkommandos der Wehrmacht über Besuche ausländischer Kommissionen in Kriegsgefangenenlagern. Militärgeschichtliche Zeitschrift, 1967, Bd. 2, Hf. 2, S. 119-134.

43 SCHECK, R. Op. cit., p. 230.

44 Ibid., p. 212. 
es were also considered. Raffael Scheck gives the following: 'Georges Smets reports the love story of a Belgian POW who was working on a farm in Bismarck, a village near Heydekrug (Memel), alone with the farmer's wife and her two little children. The woman's husband was a soldier on the Eastern front, and the prisoner himself was also married. Smets knew that the prisoner was seriously ill, and went to see him, asking him to let himself be repatriated. The prisoner refused, however, pointing out that he felt responsible for the woman and the two children, who were both holding on to his legs while he was talking with Smets. Smets later learned that the prisoner died only a few weeks after their conversation. The woman lovingly cared for his grave, bringing flowers and praying there every Saturday. The woman's husband never returned from Russia, but after the war, she and the prisoner's wife contacted each other. ${ }^{45}$ This report is not related to any criminal proceedings. One must assume that not all relationships were denounced. Moreover, Smets pointed out that serious deep relationships also received a different evaluation in court: 'The judges had to punish these relations, but they often respected them and considered sincere love as a mitigating circumstance.'46

\section{Children}

War at home is also experienced as a specific social reality, an exceptional situation. This different situation is often coupled with the tightening of norms, and even with their relaxation. Ursula Dorn (born 1935 in Königsberg) recalls: 'My mother then met a soldier [...] From this relationship, my little stepbrother Max was born. For my father, who hadn't been around for a long time and one day came on leave, the whole world probably collapsed when he saw the child. I can remember exactly the expression on his face. This was followed by a terrible marital row between father and mother, and we didn't even know what was going on, we had to witness everything full of great fear. We all cried terribly, and then my father left and did not come back for a few days.' ${ }^{47}$

Arbušauskaitè and Bubnys also cite the following case. Hedwig Franziska Pluschkewitz from Barsden (Heydekrug district) was sentenced in April 1943 by the special court in Königsberg to two years in prison for having sexual intercourse with a Belgian prisoner of war. The daughter Monika Sybilla was born of this relationship in January $1943 .{ }^{48}$

The report by the attorney general of 29 May 1943, which has already been cited several times, also addressed this area of conflict. The rapporteur stated that the

45 Ibid., pp. 118-119.

46 Ibid., p. 118.

47 DORN, U.; JÄNICKE, G. Op. cit., S. 16.

48 ARBUŠAUSKAITĖ, A.; BUBNYS, A. Op. cit., p. 56. 
number of cases in which German mothers had children by foreigners was increasing. The men on the front line could not adequately cope with this, and in the case of actions for rescission, great difficulties of proof would arise. ${ }^{49}$ The Nazi structures had to accept these unintended consequences of the war, which were extremely contrary to their racial-political views. Massive disturbances for the so strongly conjured Volksgemeinschaft became apparent.

\section{Conclusion}

Farm women in East Prussia had to overcome extreme challenges during the war, although they lived and worked in familiar surroundings. Although East Prussia was not considered a war-affected area until 1944, their living situation was nevertheless changed massively by the effects of the war and challenges in personal encounters. The massive upheavals of everyday life, and coping with the tasks of this time, have been underestimated up to now, and have hardly found their way into personal biographies. Many encounters and events of these years were associated with numerous far-reaching consequences that disappeared in the shadow of the dramatic events of the end of the war and the postwar period. It is still necessary to examine the role of women on the home front, as they were in some ways constitutive of the region.

List of previous studies quoted in the article

ARBUŠAUSKAITĖ, Arūnė Liucija; BUBNYS, Arūnas. Nazi Germany-Controlled POW Camps in the Environs of Šilutė 1939-1944. In Macikai House of Death: The WWII prisoner of war and Gulag camps 1939-1955 in the environs of Šilutè. Ed. by Edita JANKAUSKIENĖ. Vilnius, 2020, pp. 19-59.

FORWICK, Helmuth. Zur Behandlung alliierter Kriegsgefangener im Zweiten Weltkrieg. Anweisung des Oberkommandos der Wehrmacht über Besuche ausländischer Kommissionen in Kriegsgefangenenlagern. Militärgeschichtliche Zeitschrift, 1967, Bd. 2, Hf. 2, S. 119-134.

HERBERT, Ulrich. Fremdarbeiter. Politik und Praxis des "Ausländereinsatzes“ in der Kriegswirtschaft des Dritten Reiches. Berlin, 1999.

KOSSERT, Andreas. Damals in Ostpreußen. Der Untergang einer deutschen Provinz. München, 2008. KRETSCHMAR, Hans. Zum gegenwärtigen Stand der kriegsfinanzpolitischen Frage. Zeitschrift für die gesamte Staatswissenschaft, 1942, Bd. 102, Hf. 4, S. 654-701.

LIETZ, Zygmunt. Obozy jenieckie w Prusach Wschodnich, 1939-1945. Warszawa, 1982.

RÖGER, Maren; LEISEROWITZ, Ruth. Introduction: Gender and World War II in Central and Eastern Europe. In Women and Men at War. A Gender Perspective on World War II and its Aftermath in Central and Eastern Europe. Ed. by Maren RÖGER; Ruth LEISEROWITZ. Osnabrück, 2012, pp. 9-32.

SCHECK, Raffael. Love between Enemies. Western Prisoners of War and German Women in World War II. Cambridge, 2021.

49 TILITZKI, C. Op. cit., S. 237-254, here S. 245. 
SCHWARZE, Gisela. Es war wie Hexenjagd. Die vergessene Verfolgung ganz normaler Frauen im Zweiten Weltkrieg. Münster, 2010.

USCHTRIN, Günter. Wo liegt Coadjuthen? Die Geschichte eines ostpreußischen Kirchspiels im ehemaligen Memelland. Berlin, 2011.

VERGIN, Ute. Die nationalsozialistische Arbeitseinsatzverwaltung und ihre Funktionen beim Fremdarbeiter(innen)einsatz während des Zweiten Weltkriegs. Dissertation zur Erlangung des Doktorgrades. Osnabrück, 2008.

MOTERYS DAUGIASLUOKSNIAME [TAMPOS LAUKE: KASDIENIS KARO METŲ GYVENIMAS RYTŲ PRŪSIJOJE

Ruth Leiserowitz

Santrauka

Straipsnyje keliamas klausimas, koks buvo moteru kasdienis gyvenimas Antrojo pasaulinio karo metais Rytų Prūsijoje ir kaip moterys sprende papildomas problemas, kurios joms tuo metu kilo. Karo metais moterims, ypač kaime, taip pat teko susidurti su ypatingais iššūkiais, nes išskirtinè karo situacija stipriai paveikè moterų veiksmu galimybes. Ši aplinkybè visiškai prieštarauja paplitusiam teiginiui, kad „per Antrojo pasaulinio karo siaubą Rytų Prūsija buvo palaimintujų sala“" (Kossert, 2008, p. 7). Tačiau specialiai šis klausimas niekada nebuvo akcentuojamas ir nagrinèjamas, nes ji visiškai užgožè priverstinès evakuacijos ir karo pabaigos patirtys. Todell tikroji karo kasdienybė su visais jos aspektais ir sunkumais buvo nustumta j antrą planą.

Išskyrus kelias išimtis, šiame straipsnyje remiamasi publikuotais šaltiniais. Iš ligšiolinių tyrimų straipsnio tematika ypač noréčiau atkreipti dèmesi i naują Raffaelio Schecko monografiją, kurioje jis išsamiai tyrinejo Vakarų Europos karo belaisvių ir vokiečių moterų meilès santykius Antrojo pasaulinio karo metais. Nors Rytų Prūsijos regionas jo tyrime vaidina tik antraeili vaidmenį, šio straipsnio temos kontekste jis remiasi puikiais amžininkų liudijimais.

Karo kasdienybė daugiausia gulè ant moteru pečių. Dar prieš prasidedant karui buvo planuojama nustatyti maisto produktų racioną ir ịvesti maisto talonus. Ypač buvusio Klaipėdos krašto gyventojams, kurie su didele euforija šventė prijungimą prie Vokietijos Reicho, šis naujas apribojimas pablogino nuotaiką. Nors nuo 1939 m. pavasario Klaipèdos kraštas vèl priklausè Vokietijos Reichui, vietos sąlygos daugeliu atžvilgių nebuvo suvienodintos. Ivairiose srityse buvo skirtumų nuo vadinamojo „senojo Reicho“.

Kai 1941 m. vasaros pradžioje provincija tapo kariuomenės dislokacijos vieta besiruošiant artejjančiai invazijai i SSRS, civiliai gyventojai pirmą kartą pajuto, kad reikalai tampa rimti. Dar prieš karą žemės ūkyje su darbo krūviu buvo įmanoma susidoroti tik pasitelkus sezoninius darbininkus. $1941 \mathrm{~m}$. Vermachtas regione užverbavo daug vyrų, todèl darbo 
jègos èmé ypač trūkti. Tuo pat metu Rytų Prūsija tapo daugybės darbo stovyklų teritorija. Šiose stovyklose buvo laikomi tiek užsieniečiai, tiek priverstiniai darbininkai, tiek karo belaisviai. Nacių institucijos griežtai skyrè SSRS karo belaisvių ir Prancūzijos, Belgijos bei JAV ir Britanijos karo belaisvių stovyklas. Provincijoje buvo kelios karo belaisvių stovyklos, kuriose kalèjo daug karo belaisvių iš Prancūzijos, Belgijos, Lenkijos, Sovietų Sajungos ir kitų šalių kariuomenių.

Reikia įsivaizduoti, kad nacių režimas iš iprastinio darbo proceso ir gyvenimo konteksto išplèšè i karą didžiają dali produktyviausio amžiaus vyrų; mainais ju pajègumus turèjo kompensuoti tokio pat amžiaus ir tokios pat fizinès būklès vyrai, perkelti i visiškai kitą kontekstą ir čia turẻję dirbti žeminančiomis sąlygomis. Atsižvelgiant į nacių valstybès ideologiją, kuri svajojo apie grynakrauji nacionalinį kūną, tai buvo šizofreniška. Turètų būti akivaizdu, kad ši situacija visiems jos dalyviams kèlè papildomą stresą. Akivaizdu, kad ekonominiai iššūkiai vertè švelninti rasinès ideologijos nuostatų igyvendinimą.

Kaimo moterys tais laikais turejo per daug darbo ir pareigų. Reikèjo pasirūpinti šeima ir ūkiu, o vaikai taip pat pasiilgo tèvo. Be to, jos nerimavo dèl savo vyrų, kurie buvo fronte ir iš kurių paprastai gaudavo mažai naujienų, nes susirašinèjimas dažniausiai būdavo negausus. Čia atsiskleidè ir neverbalinès j̇tampos sritys, nes daugelis vyrų taip pat nerimavo, ar jų žmonos per ilgą vyrų nebuvimą namie netaps neištikimos. Be viso to, moterims reikèjo perimti žemès ūkio verslą, tam buvo pasitelkiami užsienio darbininkai, ir tai taip pat prisidèjo prie įtampos.

Moterys buvo priklausomos nuo glaudaus bendradarbiavimo su savo darbininkais. Nors jos turèjo išlaikyti aiškią distanciją nuo jų, dažnai moterims tekdavo atsidurti situacijose „vienas prieš vieną". Papildomą spaudimą kaimo moterys patyrè todèl, kad kaimo bendruomenè ịtariai stebejo, ar jos laikosi tinkamos distancijos nuo priverstinių darbininkų nacių ideologijos prasme ir ar tinkamai vykdo savo pareigas, kurių iš jų tikèjosi nacionaliniais ir rasiniais kriterijais apibrèžta bendruomenè (Volksgemeinschaft). Už fronto linijos karas buvo išgyvenamas kaip specifinè socialinè tikrovė, kaip išskirtinė situacija. Dažnai ją lydèjo normų sugriežtinimas arba sušvelninimas. Natūralu, kad tarpasmeniniai santykiai plètojosi, buvo daugybė situacijų, kai vyko flirtas, meilès romanai ar net susiklostè nuoširdūs santykiai. Vèliau vyko pasmerkimas ir bylos teisme.

Šie karo kasdienybės istorijos aspektai iki šiol atskleisti tik minimaliai. Straipsnyje aptarti tik keli klausimai, kurie dar turi būti plètojami ateities tyrimuose. 